\title{
Geotechnical Investigations for the Ponnaiyar- Palar Intra State Link Canal Project (Borrow Area and along the Canal Alignment)
}

\author{
Shahid Noor \\ Corresponding Author and Scientist ' $C$ ', \\ Central Soil and Materials Research Station, \\ Ministry of Water Resources, RD \& GR, Government of India, \\ Olof Palme Marg, Hauz Khas, New Delhi-110016. \\ Dr. R. Chitra \\ Scientist ' $E$ ', \\ Central Soil and Materials Research Station, \\ Ministry of Water Resources, RD \& GR, Government of India, \\ Olof Palme Marg, Hauz Khas, New Delhi-110016 \\ Dr. Manish Gupta \\ Scientist ' $D$ ', \\ Central Soil and Materials Research Station, \\ Ministry of Water Resources, RD \& GR, Government of India, \\ Olof Palme Marg, Hauz Khas, New Delhi-110016

\section{Dr. Amardeep Singh} \\ Scientist ' $C$ ', \\ Central Soil and Materials Research Station, \\ Ministry of Water Resources, RD \& GR, Government of India, \\ Olof Palme Marg, Hauz Khas, New Delhi-110016
}

\begin{abstract}
Rainfall is the important element of Indian economy. Although the monsoons effect most part of India, the amount of rainfall varies from heavy to scanty on different parts. There is great regional and temporal variation in the distribution of rainfall. Over $80 \%$ of the annual rainfall is received in the four rainy months of June to September. The average annual rainfall is about $125 \mathrm{~cm}$, but it has great spatial variations. This lead to excess rainfall in one region which results the flood and water shortage in other region which leads to the drought in other region. The interlinking project are envisaged with aim to transfer the water from the water surplus region the water deficit region. The Ponnaiyar (Nedungal Anicut) - Palar Intra-state Link Project of Tamil Nadu envisages diversion of $99 \mathrm{Mm}^{3}$ of flood water of Ponnaiyar river available at Krishnagiri dam to the Palar River. The main objective of the link Project is to improve the Groundwater potential to stabilize the existing command area and stabilize the enroute command areas of Tamil Nadu state. The geotechnical investigation for the proposed Ponnaiyar (Nedungal Anicut) - Palar Intra-state Link Project was undertaken by CSMRS. The paper presents the soil investigations carried out along the canal alignment of the proposed link canal.
\end{abstract}

Key Words: Geotechnical Investigations, Borrow Area Investigations, Foundation Investigations, Trial Pits, Shear, Link Canal, Compaction, Consolidation

Disclaimer: The views expressed in this paper are strictly individual views of the author and do not, in any way, represent the views of the department/organization where they are presently working.

\section{INTRODUCTION}

India is a vast country and is highly diversified in terms of natural resources and socio-economic setup. Moreover, its water resources are unevenly distributed in space and time. With increasing population and increasing aspiration 
for improved standard of living, there is an acute pressure on the demand and availability of water. In India, the river-linking project in a sensible and scientific manner will not only allow the prevention of the colossal wastage of a vitally important natural resource, flood and inundation by detaining flowing surface water of rainy seasons, but also ensure availability of water to drier areas, combating both flood and drought simultaneously. Moreover, it will generate $34,000 \mathrm{MW}$ of hydropower and irrigation to an additional 35 million hectares (135,135 square miles) of land (Sharon Gourdji, Carrie Knowlton \& Kobi Platt).

\section{INTERLINKING OF RIVERS IN INDIA}

Human societies have always tried to expand the spatial extent of availability of water by the diversion of streams or rivers. The idea of drawing water from the rivers in eastern India, which have larger run-off, in comparison to certain places in the peninsular region, where the precipitation levels are much lower, can be seen as an extension of that practice.

The country receives about $4,000 \mathrm{cu} \mathrm{km}$ of water as precipitation annually. However, unlike the precipitation patterns in the temperate regions of the world, precipitation in India is characterized by acute variations in both space and time. A large part of the total precipitation on the country is received in the Himalayan catchments of the Ganga and Brahmaputra rivers. The distribution of precipitation over India is predominantly governed by the Monsoon, as a result of which the northeastern quarter of the country receives substantially larger precipitation, in comparison with the northwestern, western and southern parts. Though the west-flowing rivers originating from the Western Ghats have substantial runoff, the spatial scope for their wider utilization is limited (Upali A. Amarasinghe et.al).

For assessing the water resources of India, the area of the country has been divided in 24 river-basins in which the west flowing rivers from the Western Ghats have all been clubbed as one. On the basis of the National Perspective on water resource development, the interlinking project has two components - the Himalayan and the Peninsular (NWDA web site). The Himalayan component includes construction of storage dams on the main tributaries of Ganga and Brahmaputra to transfer 'surplus' water to the west. The Peninsular component involves connecting rivers like Godavari and Mahanadi that have 'surplus' water with rivers like Krishna and Cauvery. A total of 31 link are envisaged, out of which 14 links will be in the Himalayan component and 17 links will be in the Peninsular component (Figure 1).

\section{PONNAIYAR - PALAR INTRA STATE LINK CANAL PROJECT}

The Ponnaiyar (Nedungal Anicut) - Palar Intra-State Link Project, Tamil Nadu envisages diversion of $99 \mathrm{Mm} 3$ of flood flows/spill waters of Ponnaiyar river available at Krishnagiri dam from the existing Nedungal Anicut, located at $16 \mathrm{~km}$ downstream of Krishnagiri Dam, to the Palar River. The main objective of the link canal project is to improve the groundwater potential for stabilizing the existing command area up to 9500 ha. which is presently irrigated through open wells and bore wells in water-short Vaniyambadi taluk of Vellore district in Palar basin and feeding enroute system of water tanks (Eris) for stabilising the enroute command areas in Krishnagiri and Vellore districts of Tamil Nadu state. Apart the above, a quantum of about 3.882 Mm3 of water is planned for domestic water supply to enroute villages of 1.52 lakh population.

The Ponnaiyar (Nedungal Anicut ) - Palar Link Canal off-takes from the left bank of the existing Nedungal Anicut at FSL $434.450 \mathrm{~m}$ and outfalls at $419.666 \mathrm{~m}$ into Kal Ar of Godd Ar, which is a tributary of Palar river near Natrampalli village of Vaniyambadi taluk. The total length of the link canal is $54.15 \mathrm{~km}$. The canal passes by gravity through Pochampalli \& Krishnagiri taluks of Krishnagiri district and Tirupattur taluk of Vellore district of Tamil Nadu.

The canal is designed as unlined canal with trapezoidal section to carry the designed discharge of 68 cumecs with a uniform bed width of $25.0 \mathrm{~m}$ and full supply depth of $2.45 \mathrm{~m}$. Uniform bed slope of 1:4500 is adopted for the entire length of the link canal. The link canal crosses $62 \mathrm{CD} / \mathrm{CM}$ structures enroute including one head regulator at off-take point and one out-fall structure at tail end.

The main features and cross drainage structures along the canal alignment of proposed Ponnaiyar (Nedungal Anicut) - Palar Intra State Link Canal Project, Tamil Nadu are given in Table 1 a \& 1 b. 


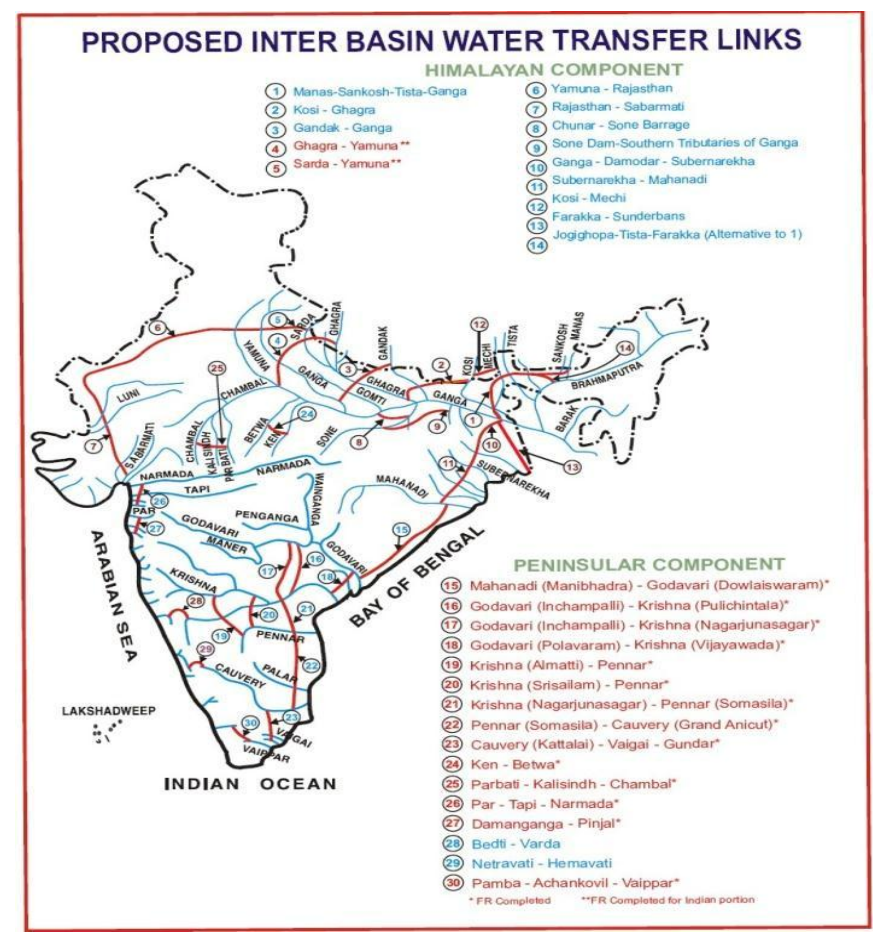

Figure 1 Proposed Interlinking of Rivers Projects in India

\section{BENEFITS FROM THE PROJECT}

The Ponnaiyar (NedungalAnicut) - Palar Intra-state Link Project of Tamil Nadu is planned as a multipurpose project with flood control, water supply and irrigation benefit in the downstream of Krisnagiri dam. The project is planned to divert the $99 \mathrm{Mm} 3$ of flood flows/spill waters of Ponnaiyar river available at Krishnagiri dam at 50\% dependability from the existing Nedungal Anicut, located at $16 \mathrm{~km}$ downstream of Krishnagiri Dam, to the Palar River (CSMRS 2015). The project will improve the groundwater potential and will stabilize the existing command area to an extent of 9500 ha which is presently being irrigated through open wells and bore wells in water-short Vaniyambadi taluk of Vellore district in Palar basin apart from feeding enroute system water tanks (Eris) for stabilizing the enroute command areas in Krishnagiri and Vellore districts of Tamil Nadu state. A quantum of about $3.882 \mathrm{Mm} 3$ of water is planned for domestic water supply to enroute villages for about 1.52 lakh population.

Table 1a : Main Features of the Link Canal

\begin{tabular}{|l|l|l|}
\hline S. No. & Feature & Characteristics \\
\hline 1 & Length of the canal & $54.15 \mathrm{~km}$ \\
\hline 2 & Shape/type of canal & $\begin{array}{l}\text { Trapezoidal } \\
\text { Unlined canal }\end{array}$ \\
\hline 3 & FSL at Off-take & $+434.450 \mathrm{~m}$ \\
\hline 4 & Bed slope of the canal & 1 in 4500 \\
\hline 5 & $\begin{array}{l}\text { Full supply depth } \\
\text { (FSD) }\end{array}$ & $2.45 \mathrm{~m}$ \\
\hline 6 & FSL at Outfall & $+419.666 \mathrm{~m}$ \\
\hline 7 & $\begin{array}{l}\text { Bed width of the } \\
\text { canal }\end{array}$ & $25 \mathrm{~m}$ \\
\hline 8 & $\begin{array}{l}\text { Side slopes of the } \\
\text { canal }\end{array}$ & $1.5 \mathrm{H}: 1 \mathrm{~V}$ \\
\hline 9 & Maximum carrying & 68 cumec \\
\hline
\end{tabular}

Table $1 \mathrm{~b}$ : Cross Drainage structures along the Canal Alignment

\begin{tabular}{|l|l|l|}
\hline S. No. & Feature & Nos. \\
\hline 1 & Head Regulator at Off take & 1 No. \\
\hline 2 & $\begin{array}{l}\text { CR cum Escape at RD 29.55km } \\
\text { at Bargur Ar.pe }\end{array}$ & 1 No. \\
\hline 3 & CR/Outfall Structure & 1 No. \\
\hline 4 & Aqueducts & 6 Nos. \\
\hline 5 & Canal Syphon & 6 Nos. \\
\hline 6 & Super Passages & 2 Nos. \\
\hline 7 & SLRB & 16 Nos. \\
\hline 8 & DLRB & 18 Nos. \\
\hline 9 & Outlets & 5 Nos. \\
\hline
\end{tabular}




\begin{tabular}{|l|l|l|}
\hline & capacity of the canal & \\
\hline 10 & $\begin{array}{l}\text { Major Rivers crossed } \\
\text { by link canal }\end{array}$ & $\begin{array}{l}\text { Mattur Ar, Bargur } \\
\text { Ar and } \\
\text { Velakkanattam Ar. }\end{array}$ \\
\hline
\end{tabular}

\begin{tabular}{|l|lr|l|}
\hline & & \\
\hline 10 & Undertunnels & 5 Nos. \\
\hline 11 & Elevated pipes/trough & 1 No. \\
\hline \multicolumn{2}{|r}{ Total } & 62 Nos. \\
\hline
\end{tabular}

\section{TOPOGRAPHY AND GEOLOGY OF THE PROJECT AREA}

The link canal project including its command area falls in the basins of the Krishna and Pennar. The topography and geology of these basins is may be studied in two parts

\section{KRISHNA BASIN}

The Krishna basin is bounded on the north by the common ridge separating it from Godavari basin, on the south and east by the Eastern Ghats and on the west by Western Ghats. Except the hills forming the watershed round the basin, the entire drainage basin of the river comprises of rolling and undulating country and a series of ridges and valleys interspersed with low hill ranges. The interior of the basin in its middle reaches is a plateau, the greater part of which is at an elevation of 300 to $600 \mathrm{~m}$. Its general slope is eastwards. Great undulating plains divided from each other by flat topped ranges of hills are the chief characteristics of this plateau. The Krishna basin consists largely of Archaean formations, part of which are covered by Deccan trap lavas, Cuddapah and Vindhyan series and faulted blocks of Gondwanas (NWDA Website)

\section{PALAR BASIN}

The upper reaches of the basin are predominantly covered by granite gneisses, Gondwanas, Cuddapah formations of Archaeans belonging to Dharwarian system with basic intrusives. The central portion of the catchment is covered by archaean crystalline hard rock and sedimentary rocks. Alluvial deposits are found all along the coastal belt and Palar River course comprising of marine and riverine deposits. Due to uplift of landmasses and tactonic activities, the archaean dharwarian hard rocks were subjected to deformation into folds and faults and also resulted in shifting of river courses in basin area (NWDA website). 


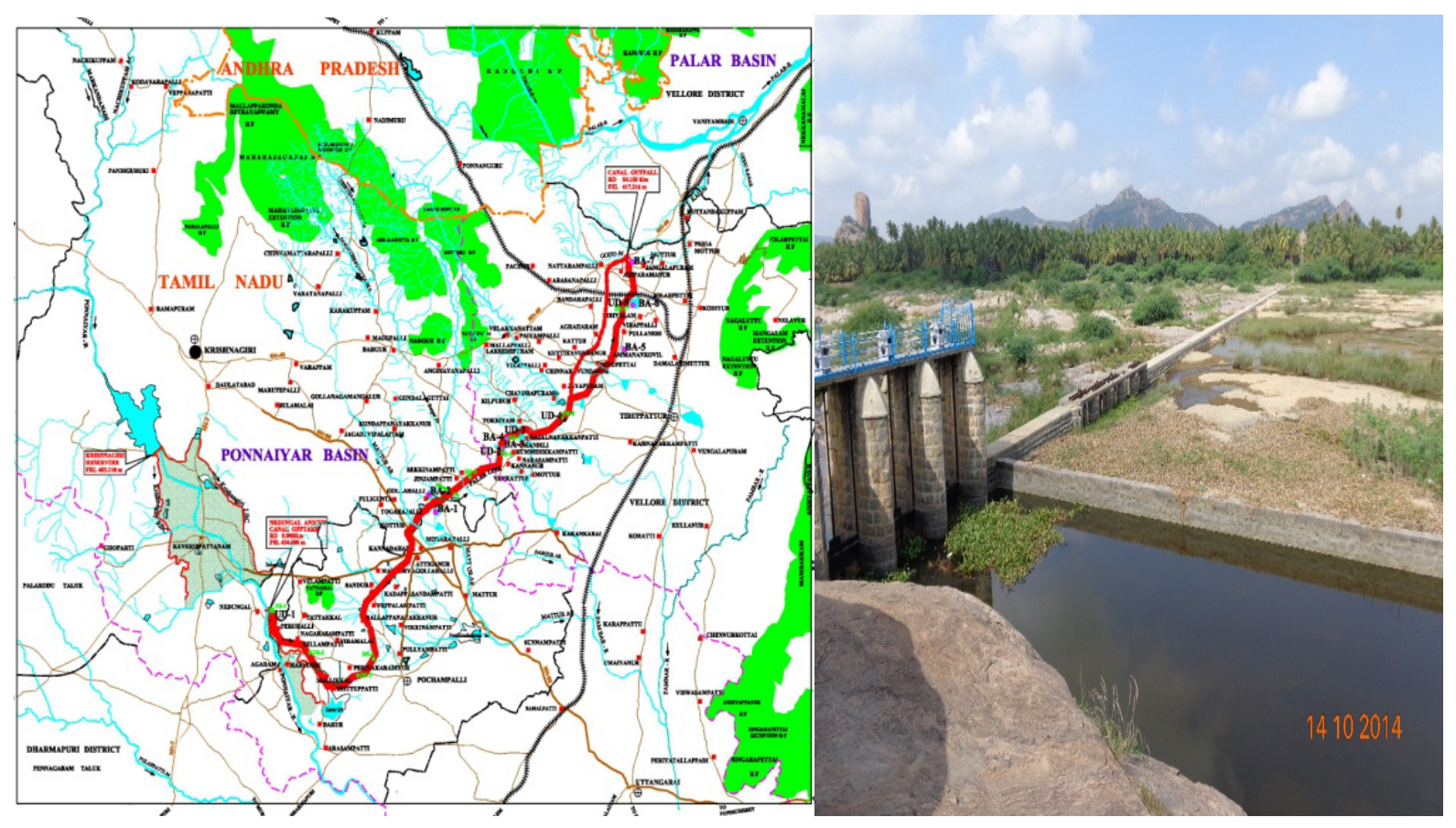

(a)

(b)

Figure 2: (a) Index Map of the Ponnaiyar (Nedungal Anicut) - Palar Intra-State Link Project

(b) off Take Point of Canal

VIII. GEOTECHNICAL INVESTIGATIONS

The geotechnical investigations involve foundation investigations at the major and minor drainage works, soil investigations along the canal alignment and borrow area investigations. The foundation investigations at major cross drainage/cross masonry structures sites involve drilling the drill hole on each side of cross drainage structure and the Standard Penetration test and insitu Permeability test beside the collection of undisturbed/representative soil samples in shelby tubes at regular intervals.

The soil investigation works along the canal alignment involves collection of undisturbed/ disturbed soil samples from the trial pits excavated at the regular intervals of 4 to $5 \mathrm{~km}$ along the canal alignment.

The undisturbed soil samples are collected in core cutters from shallow pits of size $3 \mathrm{~m} \times 3 \mathrm{~m} \times 3 \mathrm{~m}$ from the portion where the canal is in cutting and the representative disturbed soil samples are to collected in the gunny bags from the surrounding areas (borrow area) where the canal is in filling.

A total of 62 cross drainage/cross masonry structures fall along the canal alignment. Figure 2 (a) shows the index map of the Ponnaiyar (Nedungal Anicut) - Palar Intra-state Link Project. The proposed canal is $54.15 \mathrm{~km}$ long which off takes from the left bank of the existing Nedungal Anicut \{Figure 2(b)\} at FSL $434.450 \mathrm{~m}$ and outfalls at $419.666 \mathrm{~m}$ into KalAr of GoddAr, which is a tributary of Palar river near Natrampalli village of Vaniyambadi taluk. The canal passes by gravity through Pochampalli \& Krishnagiri taluks of Krishnagiri district and Tirupattur taluk of Vellore district of Tamil Nadu. During its traverse, the canal crosses the rivers MatturAr, BargurAr and Velakkanattam Ar.

The longitudinal section of the proposed canal indicate that most of the canal alignment falls in the cutting portion barring few exceptions from RD $15.323 \mathrm{~km}$ to $21.825 \mathrm{~km}$, from RD $23.000 \mathrm{~km}$ to $26.500 \mathrm{~km}$, RD $29.581 \mathrm{~km}$, from RD $33.000 \mathrm{~km}$ to $34.000 \mathrm{~km}$. and from RD $39.3060 \mathrm{~km}$ to $40.076 \mathrm{~km}$. 


\section{Field Investigations}

\section{SOIL INVESTIGATION ALONG THE CANAL ALIGNMENT}

A total of nine soil samples (5 undisturbed and 4 disturbed soil samples) were collected from the trial pits excavated at nine different locations along the canal alignment, where the canal was in cutting portion. The in-situ permeability test was carried out on in all nine trial pits. The values of coefficient of permeability presented in Table 2 indicted that the strata along the alignment of canal was pervious.

Table 2: Results of Field Permeability Test

\begin{tabular}{|c|c|c|c|}
\hline $\begin{array}{c}\mathrm{RD}, \\
\mathrm{km}\end{array}$ & $\begin{array}{c}\text { Depth } \\
, \mathrm{m}\end{array}$ & $\begin{array}{c}\mathrm{k} \\
\mathrm{cm} / \mathrm{sec}\end{array}$ & $\begin{array}{c}\text { Drainage } \\
\text { Characteristics }\end{array}$ \\
\hline 0.00 & 2.90 & $2.30 \times 10^{-4}$ & Pervious \\
\hline 5.20 & 3.00 & $2.83 \times 10^{-4}$ & Pervious \\
\hline 10.20 & 2.00 & $6.73 \times 10^{-4}$ & Pervious \\
\hline 12.00 & 2.50 & $6.06 \times 10^{-4}$ & Pervious \\
\hline 30.24 & 1.40 & $2.18 \times 10^{-4}$ & Pervious \\
\hline 34.01 & 2.30 & $1.82 \times 10^{-4}$ & Pervious \\
\hline 35.05 & 2.40 & $4.97 \times 10^{-4}$ & Pervious \\
\hline 40.45 & 0.35 & $6.30 \times 10^{-4}$ & Pervious \\
\hline 50.40 & 2.80 & $7.94 \times 10^{-4}$ & Pervious \\
\hline
\end{tabular}

\section{Laboratory Investigations}

\section{Mechanical Analysis and Atterberg Limits}

All the nine soil samples were subjected to Mechanical Analysis and Atterberg limits tests as per SP-36 (Part-1)$1978\}$. The grain size analysis of the tested soil samples indicated that the tested soil samples possess predominantly medium sand sizes followed by fine sand sizes and silt sizes. The grain sizes of the tested soil samples indicated that the clay sizes vary from $1.7 \%$ to $27.4 \%$, silt sizes vary from $4.8 \%$ to $33.1 \%$, fine sand sizes vary from $3.3 \%$ to $25.5 \%$, medium sand sizes vary from $6.2 \%$ to $50.3 \%$ and the coarse sand sizes vary from $2.6 \%$ to $22.8 \%$. The gravel size was absent in six soil samples except three soil samples and varied from $3.5 \%$ to $79.9 \%$. The plasticity index values of the tested soil samples indicated that out of the nine tested soil samples, four soil samples possess the low to medium plasticity characteristics and the remaining five soil samples exhibit the non-plasticity characteristics.

Based on the results of grain size distribution and Atterberg limits tests, out of the 9 tested soil samples, 5 soil samples fall under SM (Silty Sand), 2 soil samples fall under SC (Clayey Sand) and remaining 2 soil samples fall under GP-GC (Poorly Graded Clayey with Gravel) group of Bureau of Indian Standard soil classification system (IS:1498-1970). The graphical representations of grain size distribution of the tested soil samples are presented in Figure 3. 


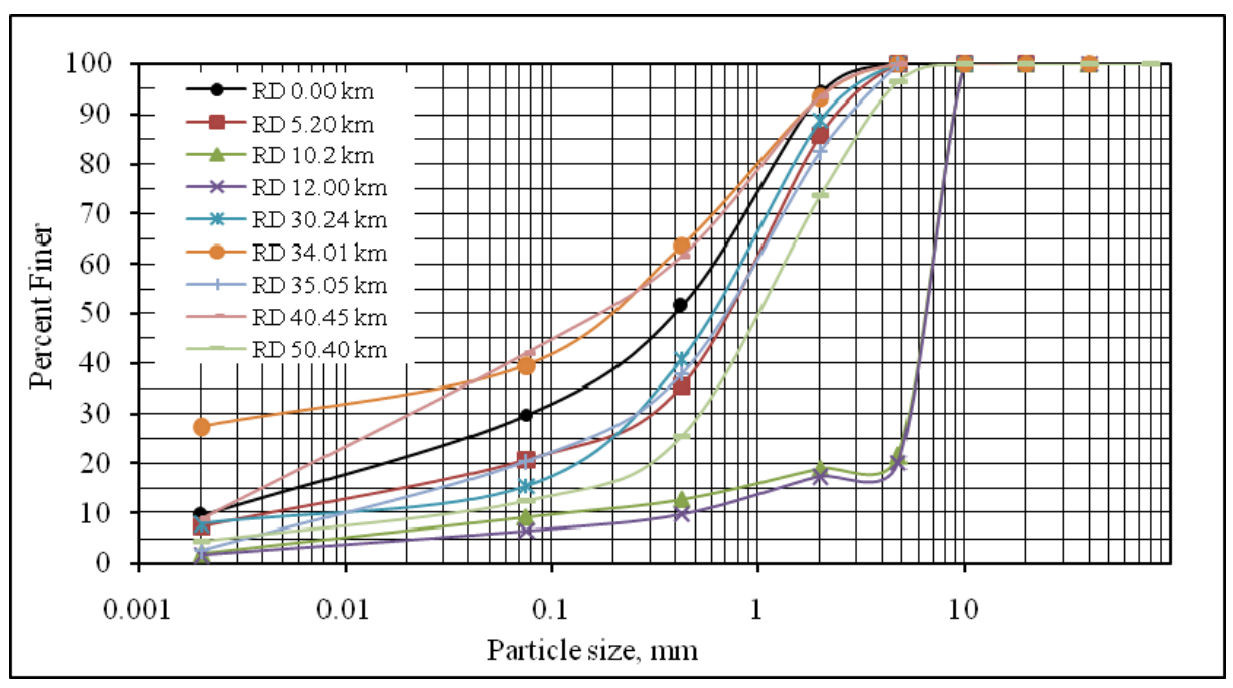

\section{Insitu Density and Natural Moisture Content}

Figure 3 : Grain Size Distribution Curve (Along the canal Alignment)

All the 5 undisturbed soil samples were subjected to the insitu density and natural moisture content tests and the values insitu density and natural moisture content vary from $1.31 \mathrm{~g} / \mathrm{cc}$ to $1.69 \mathrm{~g} / \mathrm{cc}$ and $1.93 \%$ to $24.3 \%$ respectively. The test results of insitu density and natural moisture content for the tested soil samples are presented in Table - 3.

Specific Gravity

Five soil samples were subjected to Specific Gravity test. The Specific Gravity values of the tested soil samples vary from 2.64 to 2.76 and are presented in Table -3 .

\section{Triaxial Shear}

Four selected undisturbed soil samples were subjected to Consolidated Undrained Triaxial Shear tests with pore water pressure measurement. The soil samples were consolidated and sheared under four different constant effective confining pressures of $1,2,3$ and $4 \mathrm{~kg} / \mathrm{cm}^{2}$ respectively after achieving full saturation by back pressure. The total shear strength parameters total cohesion (c) and total angle of shearing resistance $(\phi)$ of the tested soil samples vary from $0.08 \mathrm{~kg} / \mathrm{cm}^{2}$ to $0.17 \mathrm{~kg} / \mathrm{cm}^{2}$ and $22.1^{\circ}$ to $25.2^{\circ}$ respectively. The effective shear strength parameters effective cohesion $\left(\mathrm{c}^{\prime}\right)$ and effective angle of shearing resistance $\left(\phi^{\prime}\right)$ of the tested soil samples vary from $0.00 \mathrm{~kg} / \mathrm{cm}^{2}$ to 0.09 $\mathrm{kg} / \mathrm{cm}^{2}$ and $29.9^{\circ}$ to $32.3^{\circ}$ respectively. The results of Triaxial Shear tests - Consolidated Undrained with pore water pressure measurement of the tested soil samples are presented in Table -4 .

\section{One Dimensional Consolidation}

Four selected soil undisturbed soil samples were subjected to One Dimensional Consolidation test for ascertaining its consolidation and compressibility characteristics. All the soil sampleswere tested at different stress levels viz. $0.25,0.5,1.0,2.0,4.0$ and $8.0 \mathrm{~kg} / \mathrm{cm} 2$ respectively. The test results indicate that the tested soil samples exhibit medium compressibility characteristics. The consolidation test results are presented in Tables -5 to 7 . 
Table 4 : Triaxial Shear Test Results

\begin{tabular}{|c|c|c|c|c|}
\hline \multirow{2}{*}{\begin{tabular}{c}
\multirow{2}{*}{$\mathrm{RD}$} \\
$\mathrm{km}$
\end{tabular}} & \multicolumn{4}{|c|}{ Triaxial Shear Test } \\
\cline { 2 - 5 } & \multicolumn{2}{|c|}{$\begin{array}{c}\text { Total shear } \\
\text { parameter }\end{array}$} & \multicolumn{2}{c|}{$\begin{array}{c}\text { Effective shear } \\
\text { parameter }\end{array}$} \\
\cline { 2 - 5 } & $\begin{array}{c}\mathrm{c} \\
\mathrm{kg} / \mathrm{cm}^{2}\end{array}$ & $\begin{array}{c}\phi \\
\text { Degrees }\end{array}$ & $\begin{array}{c}\mathrm{c}^{\prime} \\
\mathrm{kg} / \mathrm{cm}^{2}\end{array}$ & $\begin{array}{c}\phi^{\prime} \\
\text { Degrees }\end{array}$ \\
\hline 0.00 & 0.17 & $25.2^{\circ}$ & 0.08 & $32.1^{\circ}$ \\
\hline 30.01 & 0.17 & $24.9^{\circ}$ & 0.09 & $32.3^{\circ}$ \\
\hline 40.45 & 0.16 & $23.2^{\circ}$ & 0.09 & $30.8^{\circ}$ \\
\hline 50.40 & 0.08 & $22.1^{\circ}$ & 0.00 & $29.9^{\circ}$ \\
\hline
\end{tabular}

Table 5: Consolidation Test results, $\mathrm{C}_{\mathrm{v}}$

\begin{tabular}{|c|c|c|c|c|c|}
\hline \multirow{3}{*}{$\begin{array}{l}\mathrm{RD}, \\
\mathrm{km}\end{array}$} & \multicolumn{5}{|c|}{ Coefficient of Consolidation, $\mathrm{C}_{\mathrm{v}} \times 10^{-4} \mathrm{~cm}^{2} / \mathrm{kg}$} \\
\hline & \multicolumn{5}{|c|}{ Stress level, $\mathrm{kg} / \mathrm{cm}^{2}$} \\
\hline & $\begin{array}{c}0.25- \\
0.50 \\
\end{array}$ & $\begin{array}{c}0.50- \\
1.0 \\
\end{array}$ & $1.0-2.0$ & $2.0-4.0$ & $\begin{array}{c}4.0- \\
8.0 \\
\end{array}$ \\
\hline 0.00 & 3.47 & 3.03 & 2.80 & 2.56 & 2.25 \\
\hline 30.01 & 1.55 & 1.35 & 1.07 & 0.86 & 0.70 \\
\hline 40.45 & 8.46 & 4.73 & 3.86 & 3.28 & 2.84 \\
\hline 50.40 & 10.45 & 7.23 & 5.17 & 3.92 & 2.95 \\
\hline
\end{tabular}

Table 7: Consolidation Test results, $\mathrm{C}_{\mathrm{c}} \& \mathrm{C}_{\mathrm{s}}$

\begin{tabular}{|l|c|c|c|c|c|}
\hline \multirow{3}{*}{$\begin{array}{l}\text { RD, } \\
\mathrm{km}\end{array}$} & \multicolumn{5}{|c|}{ Coefficient of Volume Compressibility, $\mathrm{m}_{\mathrm{v}} \times$} \\
\cline { 2 - 6 } & \multicolumn{5}{|c|}{$\mathrm{cm}^{2} / \mathrm{kg}$} \\
\cline { 2 - 6 } & $0.25-$ & $0.50-$ & $1.0-$ & $2.0-$ & $4.0-$ \\
& 0.50 & 1.0 & 2.0 & 4.0 & 8.0 \\
\hline 0.00 & 4.73 & 3.22 & 1.70 & 1.69 & 0.73 \\
\hline 30.01 & 7.38 & 5.44 & 3.91 & 1.78 & 0.96 \\
\hline 40.45 & 7.10 & 5.12 & 2.09 & 1.04 & 0.66 \\
\hline 50.40 & 8.55 & 6.21 & 3.47 & 1.86 & 0.79 \\
\hline
\end{tabular}

\begin{tabular}{|l|c|c|}
\hline $\begin{array}{l}\mathrm{RD}, \\
\mathrm{km}\end{array}$ & $\begin{array}{c}\text { Compression } \\
\text { Index, } \mathrm{C}_{\mathrm{c}}\end{array}$ & $\begin{array}{c}\text { Swelling } \\
\text { Index, } \mathrm{C}_{\mathrm{s}}\end{array}$ \\
\hline 0.00 & 0.1115 & 0.0137 \\
\hline 30.01 & 0.1230 & 0.0292 \\
\hline 40.45 & 0.1272 & 0.0147 \\
\hline 50.40 & 0.1296 & 0.0141 \\
\hline
\end{tabular}

\section{Borrow Area Investigations}

A total of seven disturbed samples were collected from the trial pits excavated at seven different locations in the adjoining area of canal alignment, where the canal was in filling portion.

\section{LABORATORY INVESTIGATIONS}

\section{Mechanical Analysis and Atterberg limits}

All the 7 soil samples were subjected to Mechanical Analysis and Atterberg limits tests. The grain size analysis of the tested soil samples indicate that the tested soil samples possess predominantly medium sand sizes followed by the fine sand sizes. The grain sizes of the tested soil samples indicate that the clay sizes vary from $0.4 \%$ to $11.5 \%$, silt sizes vary from $13.0 \%$ to $20.4 \%$, fine sand sizes vary from $13.6 \%$ to $29.0 \%$, medium sand sizes vary from $39.2 \%$ to $61.7 \%$ and the coarse sand sizes vary from $1.9 \%$ to $13.8 \%$. The gravel sizes are totally absent in all the tested soil samples. The plasticity index values of the tested soil samples indicate that out of the seven tested soil samples, six soil samples possess the low to medium plasticity characteristics and the remaining one soil sample exhibit the non-plasticity characteristics. Based on the results of grain size distribution and Atterberg limits tests, out of the 7 tested soil samples, 4 soil samples fall under SC (Clayey Sand) and the remaining 3 soil samples fall under SM (Silty Sand) group of Bureau of Indian Standard soil classification system. The graphical representations of grain size distribution of the tested soil samples are presented in Figures 4.

\section{Standard Proctor Compaction and Specific Gravity}

Six selected soil samples were subjected to Standard Proctor Compaction test. The values of Maximum Dry Density and Optimum Moisture Content of the tested soil samples vary from $1.711 \mathrm{~g} / \mathrm{cc}$ to $2.012 \mathrm{~g} / \mathrm{cc}$ and $8.2 \%$ to $18.7 \%$ 
respectively. The graphical representations of the Standard Proctor Compaction test results of the tested materials are presented in Figures 5. The Specific Gravity values of the tested soil samples vary from 2.67 to 2.76.

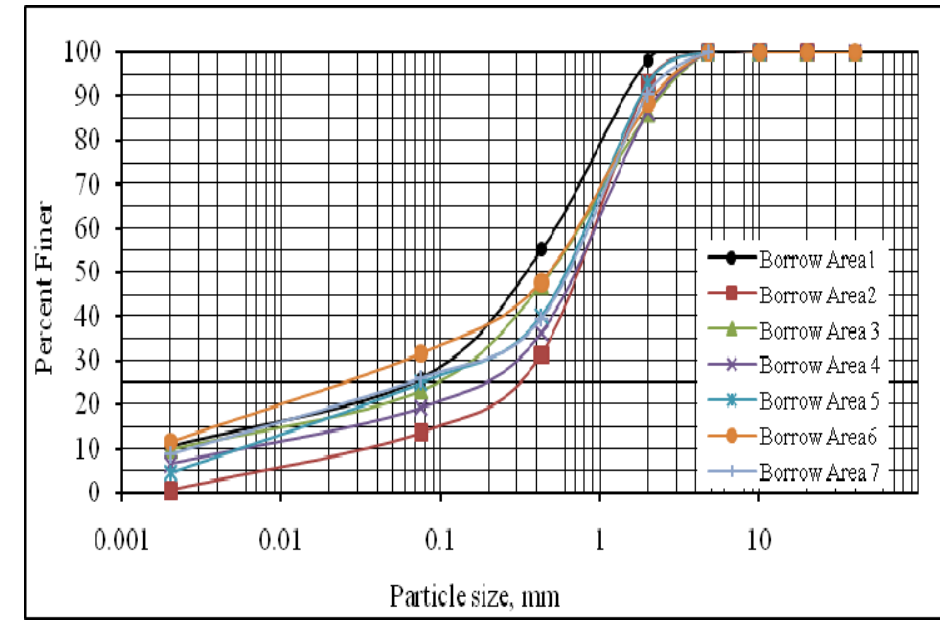

Figure 4: Grain Size Distribution Curve

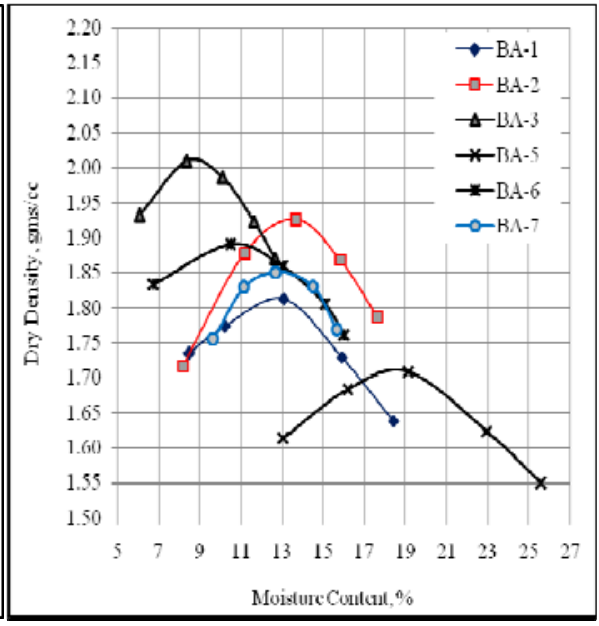

Figure 5: Standard Proctor Compaction Curve

\section{Triaxial Shear}

Six selected soil samples were subjected to Consolidated Undrained Triaxial Shear tests with pore water pressure measurement. The soil samples were compacted at $98 \%$ of the maximum dry density, consolidated and sheared under four different constant effective confining pressures of $1,2,3$ and $4 \mathrm{~kg} / \mathrm{cm}^{2}$ respectively after achieving full saturation by back pressure. The total shear strength parameters total cohesion (c) and total angle of shearing resistance $(\phi)$ of the tested soil samples vary from $0.11 \mathrm{~kg} / \mathrm{cm}^{2}$ to $0.17 \mathrm{~kg} / \mathrm{cm}^{2}$ and $22.9^{\circ}$ to $26.0^{\circ}$ respectively. The effective shear strength parameters effective cohesion $\left(\mathrm{c}^{\prime}\right)$ and effective angle of shearing resistance $\left(\phi^{\prime}\right)$ of the tested soil samples vary from $0.02 \mathrm{~kg} / \mathrm{cm}^{2}$ to $0.06 \mathrm{~kg} / \mathrm{cm}^{2}$ and $30.2^{\circ}$ to $33.1^{\circ}$ respectively. The results of Triaxial Shear tests - Consolidated Undrained with pore water pressure measurement of the tested soil samples are presented in Table -8 .

Table 8: Triaxial Shear Test Results

\begin{tabular}{|c|c|c|c|c|c|}
\hline \multirow{3}{*}{ Borrow Area } & \multirow{3}{*}{$\begin{array}{l}\mathrm{RD} \\
(\mathrm{m})\end{array}$} & \multicolumn{4}{|c|}{$\begin{array}{c}\text { Triaxial Shear Test - Consolidated Undrained with Pore Water } \\
\text { Pressure Measurement }\end{array}$} \\
\hline & & \multicolumn{2}{|c|}{ Total shear parameter } & \multicolumn{2}{|c|}{ Effective shear parameter } \\
\hline & & $\begin{array}{c}\mathrm{c} \\
\mathrm{kg} / \mathrm{cm}^{2}\end{array}$ & $\begin{array}{c}\phi \\
\text { Degrees }\end{array}$ & $\begin{array}{c}\mathrm{c}^{\prime} \\
\mathrm{kg} / \mathrm{cm}^{2}\end{array}$ & $\begin{array}{c}\phi^{\prime} \\
\text { Degrees }\end{array}$ \\
\hline BA-1 & 26.35 & 0.13 & $26.0^{\circ}$ & 0.04 & $32.8^{\circ}$ \\
\hline BA-2 & 26.90 & 0.11 & $25.2^{\circ}$ & 0.02 & $32.9^{\circ}$ \\
\hline BA-3 & 34.01 & 0.11 & $24.2^{\circ}$ & 0.03 & $33.1^{\circ}$ \\
\hline BA-4 & 35.05 & 0.17 & $22.9^{\circ}$ & 0.06 & $30.1^{\circ}$ \\
\hline BA-5 & 51.00 & 0.11 & $23.3^{\circ}$ & 0.03 & $30.2^{\circ}$ \\
\hline BA-6 & 54.15 & 0.12 & $24.1^{\circ}$ & 0.02 & $31.3^{\circ}$ \\
\hline
\end{tabular}

\section{One Dimensional Consolidation}

Four selected soil samples were subjected to One Dimensional Consolidation test for ascertaining its consolidation and compressibility characteristics. The test was carried out on the materials passing through the $2 \mathrm{~mm}$ sieve size. 
The soil samples were compacted at $98 \%$ of the maximum dry density and tested at different stress levels viz. 0.25 , $0.5,1.0,2.0,4.0$ and $8.0 \mathrm{~kg} / \mathrm{cm} 2$ respectively. The test results indicate that the tested soil samples exhibit low compressibility characteristics. The consolidation test results are presented in Tables -9 to 10 .

Table 9 : Consolidation Test results

\begin{tabular}{|c|c|c|c|c|c|c|}
\hline \multirow{3}{*}{$\begin{array}{c}\text { Borro } \\
\mathrm{W}\end{array}$} & \multirow{3}{*}{$\begin{array}{c}\mathrm{RD}, \\
\text { Area }\end{array}$} & \multicolumn{5}{|c|}{$\begin{array}{c}\text { Coefficient of Consolidation, } \mathrm{C}_{\mathrm{v}} \times \\
10^{-4} \mathrm{~cm}^{2} / \mathrm{kg}\end{array}$} \\
\cline { 3 - 7 } & & \multicolumn{5}{|c|}{ Stress level, $\mathrm{kg} / \mathrm{cm}^{2}$} \\
\cline { 3 - 7 } & & $\begin{array}{c}0.25 \\
-\end{array}$ & $\begin{array}{c}0.5- \\
1.0\end{array}$ & $\begin{array}{c}1.0- \\
2.0\end{array}$ & $\begin{array}{c}2.0- \\
4.0\end{array}$ & $\begin{array}{c}4.0- \\
8.0\end{array}$ \\
\hline BA-1 & 26.35 & 5.59 & 3.94 & 3.39 & 3.11 & 2.70 \\
\hline BA-2 & 26.90 & 5.74 & 4.61 & 3.47 & 3.15 & 2.77 \\
\hline BA-3 & 34.01 & 5.36 & 4.53 & 3.45 & 3.02 & 2.71 \\
\hline BA-5 & 51.00 & 8.02 & 4.85 & 3.54 & 2.84 & 2.35 \\
\hline BA-6 & 54.15 & 6.94 & 5.99 & 3.84 & 2.74 & 2.51 \\
\hline
\end{tabular}

\begin{tabular}{|c|c|c|c|c|c|c|}
\hline & & \multicolumn{5}{|c|}{ Coefficient of Volume } \\
Compressibility, $\mathrm{m}_{\mathrm{v}} \times 10^{-2} \mathrm{~cm}^{2} / \mathrm{kg}$ \\
\cline { 3 - 7 } $\begin{array}{c}\text { Borro } \\
\mathrm{w} \\
\text { Area }\end{array}$ & \multirow{2}{*}{$\begin{array}{c}\mathrm{RD}, \\
\mathrm{km}\end{array}$} & \multicolumn{5}{|c|}{ Stress level, $\mathrm{kg} / \mathrm{cm}^{2}$} \\
\cline { 3 - 7 } & & $\begin{array}{c}0.25 \\
-\end{array}$ & $\begin{array}{c}0.5- \\
1.0\end{array}$ & $\begin{array}{c}1.0- \\
2.0\end{array}$ & $\begin{array}{c}2.0- \\
4.0\end{array}$ & $\begin{array}{c}4.0- \\
8.0\end{array}$ \\
\hline BA-1 & 26.35 & 4.52 & 2.62 & 1.24 & 0.76 & 0.55 \\
\hline BA-2 & 26.90 & 3.18 & 1.86 & 1.35 & 0.83 & 0.61 \\
\hline BA-3 & 34.01 & 2.78 & 1.46 & 1.28 & 0.80 & 0.58 \\
\hline BA-5 & 51.00 & 3.02 & 1.75 & 1.60 & 1.24 & 0.71 \\
\hline BA-6 & 54.15 & 7.76 & 4.10 & 1.81 & 1.05 & 0.50 \\
\hline
\end{tabular}

Laboratory Permeability Test

Five selected soil samples were subjected to the laboratory permeability test using falling head method. The soil samples were compacted at $98 \%$ of the maximum dry density. The results of laboratory permeability test indicate that out of the 5 tested soil samples, 3 soil samples possess impervious drainage characteristics and remaining 2 soil samples possess semi-pervious drainage characteristics. The laboratory permeability test results are presented in Table - 11.

Table 10: Consolidation Test results, $\mathrm{C}_{\mathrm{c}} \& \mathrm{C}_{\mathrm{s}}$

Table 11: Laboratory Permeability Test Results

\begin{tabular}{|c|c|c|c|}
\hline $\begin{array}{c}\text { Borrow } \\
\text { Area }\end{array}$ & $\mathrm{RD}, \mathrm{km}$ & $\begin{array}{c}\text { Compression } \\
\text { Index, } \mathrm{C}_{\mathrm{c}}\end{array}$ & $\begin{array}{c}\text { Swelling } \\
\text { Index, } \mathrm{C}_{\mathrm{s}}\end{array}$ \\
\hline BA-1 & 26.35 & 0.0747 & 0.0187 \\
\hline BA-2 & 26.90 & 0.758 & 0.0191 \\
\hline BA-3 & 34.01 & 0.0728 & 0.0114 \\
\hline BA-5 & 47.00 & 0.0769 & 0.0224 \\
\hline BA-6 & 51.00 & 0.0982 & 0.0188 \\
\hline
\end{tabular}

\begin{tabular}{|c|c|c|c|}
\hline $\begin{array}{c}\text { Borrow } \\
\text { Area }\end{array}$ & $\begin{array}{c}\mathrm{RD}, \\
\mathrm{km}\end{array}$ & $\begin{array}{c}\text { Coefficients } \\
\text { of } \\
\text { Permeability }\end{array}$ & $\begin{array}{c}\text { Drainage } \\
\text { Characteristics }\end{array}$ \\
\hline BA-1 & 26.35 & $2.47 \times 10^{-7}$ & Impervious \\
\hline BA-2 & 26.90 & $7.22 \times 10^{-5}$ & Semi-pervious \\
\hline BA-3 & 34.01 & $2.21 \times 10^{-7}$ & Impervious \\
\hline BA-5 & 47.00 & $3.47 \times 10^{-5}$ & Semi-pervious \\
\hline BA-6 & 51.00 & $1.64 \times 10^{-7}$ & Impervious \\
\hline
\end{tabular}

\section{Chemical Analysis}

Five selected soil samples were subjected to chemical analysis with particular reference to $\mathrm{PH}, \mathrm{CaCO}$, Total Soluble Solids, Water Soluble Sulphates, Water Soluble Chloride and Organic Matter. The test results of chemical analysis indicate the normal behavior of soil.

\section{CONCLUSIONS}


Based upon the findings of geotechnical investigations carried out for borrow area investigation and along the canal alignment for the proposed Ponnaiyar (Nedungal Anicut) - Palar Intra-State Link Project, Tamilnadu, the following conclusions have been arrived at.

\section{A. Soil Investigation along the Canal Alignment}

- Based on the Insitu Permeability test, it is inferred that soil strata possess pervious drainage characteristics.

- The grain size analysis of the tested soil samples indicate that the tested soil samples possess predominantly medium sand sizes followed by the fine sand sizes and silt sizes. The plasticity index values of the tested soil samples indicated that out of the nine tested soil samples, four soil samples possess the low to medium plasticity characteristics and the remaining five soil samples exhibit the non-plasticity characteristics.

- The Insitu Density test values indicate that the tested foundation strata exhibit loose to medium compactness.

- Based on the results of Triaxial Shear tests conducted on the soil samples, it is inferred that the tested soil samples are likely to exhibit good/very good shear strength characteristics.

- Based on the One Dimensional Consolidation test conducted on the undisturbed soil samples, it is inferred that that soil strata along the canal alignment are likely to undergo in general medium compressibility depending upon the imposed loads.

\section{B. Soil Investigation for the Borrow Areas along the Canal Alignment}

- The grain size analysis of the tested soil samples indicate that the tested soil samples possess predominantly medium sand sizes followed by the fine sand sizes and silt sizes. The plasticity index values of the tested soil samples indicate that out of the seven tested soil samples, six soil samples possess the low to medium plasticity characteristics and the remaining one soil sample exhibit the non-plasticity characteristics.

- Based on the Standard Proctor Compaction tests, it is inferred that soil samples are capable of achieving very good compaction densities.

- Based on the results of Triaxial Shear tests conducted on the soil samples, it is inferred that tested soil samples are likely to exhibit very good shear strength characteristics.

- Based on the One Dimensional Consolidation test conducted on the soil samples, it is inferred that borrow area materials are likely to undergo in general low compressibility depending upon the imposed loads.

- The results of Laboratory Permeability test indicate that the tested soil samples possess semi-pervious to impervious drainage characteristics.

\section{ACKNOWLEDGEMENTS}

The authors are grateful to the Director, CSMRS for his support and encouragement during the investigations. The authors also acknowledge the contribution of CSMRS officers for their active involvement of investigations. The author also acknowledge the support and help extended by the NWDA to CSMRS team during the geotechnical investigations for the proposed Ponnaiyar (Nedungal Anicut) - Palar Intra-State Link Project, Tamilnadu,.

\section{REFERENCES}

[1] B.M. Das (1994), "Principles of Soil Engineering" third Edition, PWS Publishers, Boston

[2] CSMRS Report on "Report on Laboratory Investigations on Soil Samples from Borrow Areas along the Canal Alignment for the Proposed Ponnaiyar (Nedungal Anicut) - Palar Intra State Link Canal Project,Tamil Nadu”, (Report No. 01/Soil-I/SoilI/CSMRS/E/06/2015, June 2015)

[3] CSMRS Report on "Report on Laboratory Investigations on Soil Samples along the Canal Alignment (Cutting Portion)for the Proposed Ponnaiyar (NedungalAnicut) - Palar Intra State $\quad$ Link Canal Project, Tamil Nadu”, (Report No. 02/Soil-I/SoilI/CSMRS/E/06/2015, June 2015)

[4] EM 1110-2-2300, (1982), Earth manual, Publication of United States Bureau of Reclamation 
[5] Fell, R., Macgregor, P., \& Stapledon, D. (1992), Geotechnical Engineering of Embankment dams

[6] IS 1498-1970: Classification and Identifications of Soils for General Engineering Purposes.

[7] SP-36 (Part-1)-1978: Standard Publication on Soil Testing in laboratory, Bureau of Indian Standards

[8] Master Thesis of Sharon Gourdji, Carrie Knowlton \& Kobi Platt "Indian Inter-linking of Rivers: A Preliminary Evaluation” 2005

[9] Upali A. Amarasinghe, Bharat R. Sharma, Noel Aloysius, Christopher Scott, Vladimir Smakhtin and Charlotte de Fraiture "Spatial Variation in Water Supply and Demand across River Basins of India" IWMI 83, Research Report

[10] Ministry of Water Resources, River Development and Ganga Rejuvenation official web site, http://wrmin.nic.in/

[11] National Water Development Agency (NWDA), official web site, http:/nwda.gov.in/ 